\title{
DESAIN KARAKTER BERBASIS PADA WANDA WAYANG BIMA
}

\section{Dodi Hilman, Tubagus Zufri}

\author{
Universitas BinaNusantara \\ oldtimedodi@gmail.com,zufri.thez@gmail.com
}

\begin{abstract}
Abstrak
Desain karakter merupakan bagian penting dalam produksi komik, animasi dan game. Karakter merupakan entitas profil yang akan berperan dalam konteks tertentu dalam menyampaikan muatan ideologis yang menjadi representasi suatu kelompok. Desain karakter merupakan upaya menghidupkan tokoh imajiner. Dalam perkembangan industri komik dan animasi di Indonesia, desain karakter lebih sering baru dilihat sebatas aspek visual belaka, sehingga tokoh-tokoh yang muncul dalam komik atau animasi di Indonesia seringkali terlihat belum dirancang secara matang. Komik, animasi dan game merupakan media yang kerap digunakan untuk menyampaikan materi pedidikan baik yang bersifat formal maupun informal. Penelitian ini dimaksudkan untuk melakukan eksplorasi desain karakter berbasis kekayaan visual, filosofis dan ideologis yang dimiliki Wayang Bima (Golek dan Kulit) yang dapat diapresiasi oleh anak Sekolah Dasar
\end{abstract}

Kata Kunci: Desain Karakter, Wayang Bima, Pendidikan

\section{PENDAHULUAN}

Animasi sebagai medium storytelling, harus mampu membangun suatu hubungan dengan audience sehingga pesan, informasi, atau apapun yang menjadi muatannya dapat berhasil mencapai tujuannya. Banyak pesan yang dapat ditangkap secara visual dengan melihat perbedaan pada bentuk yang ditampilkan. Guna mendapatkan bentuk yang berbeda dengan bentuk lainnya maka diperlukan proses perancangan yang memiliki muatan riset yang cukup.

Sudah saatnya kita memberikan perhatian memadai pada proses desain karakter. Karakter seyogyanya diciptakan tidak hanya bermodalkan sketsa kasar tanpa studi yang lebih matang diluar aspek visual. Proses personifikasi suatu karakter harus mencakup berbagai aspek secara menyeluruh seperti visual, psikologis, bahasa, ideologi dan lain sebagainya. Perhatian yang lebih serius terhadap perancangan karakter akan menghadirkan alternatif desain karakter ditengah bentu-bentuk yang memiliki keseragaman yang tinggi dari produk-produk impor yang memberikan dampak luar biasa tidak saja kepada para pemirsa, tetapi juga kepada para perancangnya.

Wayang (Golek dan Kulit) sebagai salah satu khasanah budaya Indonesia potensial dikembangkan dan bisa menjadi batu pijakan dalam eksplorasi desain karakter kontemporer. Wayang Golek dan Kulit) memuat berbagai macam karakter dengan simbolisasi yang lebih dekat dengan akar budaya Indonesia, sehingga pengembangan desain karakter dari Wayang akan sangat relevan bagi perkembangan desain karakter yang kelak dapat memiliki identitas yang dapat dikenali berasal dari Indonesia.

\section{Urgensi (Keutamaan) Penelitian}

Indonesia sebagai negara yang memiliki ragam budaya yang sangat kaya dalam hal ini Wayang,mulai kurang diapresiasi oleh generasi muda saat ini. Untuk memperkenalkan budaya secara menyeluruh, tentunya memerlukan effort yang sangat tinggi baik itu secara biaya 
maupun waktu.Salahsatu upaya yang bisa di di lakukan adalah dengan melakukan penetrasi sedikit demi sedikit kepada generasi muda.Hal ini bisa kita lakukan lebih mudah bila kita mencoba untuk memperkenalkannya dengan bahasa (visual ) yang dapat mudah di kenali oleh generasi muda saat ini.Karakter berbasis Wanda pada tokoh Wayang bima dapat menjadi jembatan antara budaya dan minat pada generasi muda kita,dan di harapkan melalui minat yang tumbuh terhadap salah satu karakter Wayang ini generasai muda kita akan tumbuh rasa keingin tahuanya yang lebih besar terhadap budaya Indonesia khususnya Wayang.

Desain karakter bukan sekedar menyangkut gambar atau model tetapi selalu menyimpan pesan, gagasan, filosofi bahkan ideologi tertentu sehingga bisa menjadi cerminan kondisi sosial masyarakat dimana karya tersebut dilahirkan. Perancangan yang serius pada karakter untuk komik dan animasi lokal bisa turut mempengaruhi kondisi psikologi sosial menuju kearah perbaikan jika dimanfaatkan secara tepat.

Objek penelitian ini adalah Wanda Wayang Bima(Golek dan Kulit) meliputi aspek visual, filosofis dan ideologisnya untuk kemudian diformulasikan sebagai set desain karakter yang aplikatif disesuaikan dengan audiens anak usia Sekolah Dasar.

\section{Sejarah Wayang Kulit}

Wayang merupakan salah satu puncak seni budaya bangsa Indonesia yang paling menonjol di antara banyak karya budaya lainnya. Budaya Wayang meliputi seni peran, seni suara, seni musik, seni tutur, seni sastra, seni lukis, seni pahat, dan juga perlambang. Budaya Wayang, yang terus berkembang dari zaman ke zaman, juga merupakan media dakwah, penerangan, pendidikan, hiburan, pemahaman filsafat, serta hiburan.

Menurut penelitian para ahli sejarah kebudayaan, budaya Wayang merupakan budaya asli Indonesia, khususnya di Pulau Jawa. Keberadaan Wayang sudah berabad-abad sebelum agama Hindu masuk ke Pulau Jawa. Walaupun cerita Wayang yang populer di masyarakat masa kini merupakan adaptasi dari karya sastra India, yaitu Ramayana dan Mahabarata . Kedua induk cerita itu dalam pewayangan banyak mengalami pengubahan dan penambahan untuk menyesuaikannya dengan falsafah asli Indonesia.

Penyesuaian konsep filsafat ini juga menyangkut pada pandangan filosofis masyarakat Jawa terhadap kedudukan para dewa dalam pewayangan. Para dewa dalam pewayangan bukan lagi merupakan sesuatu yang bebas dari salah, melainkan seperti juga makhluk Tuhan lainnya, kadang-kadang bertindak keliru, dan bisa jadi khilaf. Hadirnya tokoh panakawan dalam pewayangan sengaja diciptakan para budayawan Indonesia (tepatnya budayawan Jawa) untuk memperkuat konsep filsafat bahwa di dunia ini tidak ada makhluk yang benar-benar baik, dan yang benar-benar jahat. Setiap makhluk selalu menyandang unsur kebaikan dan kejahatan.

Budaya Wayang diperkirakan sudah lahir di Indonesia setidaknya pada zaman pemerintahan Prabu Airlangga, raja Kahuripan (976 -1012), yakni ketika kerajaan di Jawa Timur itu sedang makmur-makmurnya. Karya sastra yang menjadi bahan cerita Wayang sudah ditulis oleh para pujangga Indonesia, sejak abad X. Antara lain, naskah sastra Kitab Ramayana Kakawin berbahasa Jawa Kuna ditulis pada masa pemerintahan raja Dyah Balitung (989-910), yang merupakan gubahan dari Kitab Ramayana karangan pujangga India, Walmiki . Selanjutnya, para pujangga Jawa tidak lagi hanya menerjemahkan Ramayana dan Mahabarata ke bahasa Jawa Kuna, tetapi menggubahnya dan menceritakan kembali dengan memasukkan falsafah Jawa ke dalamnya. Contohnya, karya Empu Kanwa Arjunawiwaha Kakawin, yang merupakan gubahan yang berinduk pada Kitab Mahabarata. Gubahan lain yang lebih nyata bedanya derigan cerita asli versi India, adalah Baratayuda Kakawin karya Empu Sedah dan Empu Panuluh. Karya agung ini dikerjakan pada masa pemerintahan Prabu Jayabaya, raja Kediri (1130 - 1160). 
Kata "Wayang” diduga berasal dari kata "wewa yangan”, yang artinya bayangan. Dugaan ini sesuai dengan kenyataan pada pergelaran Wayang Kulit yang menggunakan kelir, secarik kain, sebagai pembatas antara dalang yang memainkan Wayang, dan penonton di balik kelir itu. Penonton hanya menyaksikan gerakan-gerakan Wayang melalui bayangan yang jatuh pada kelir. Pada masa itu pergelaran Wayang hanya diiringi oleh seperangkat gamelan sederhana yang terdiri atas saron, todung (sejenis seruling) dan kemanak. Jenis gamelan lain dan pesinden pada masa itu diduga belum ada.

Untuk lebih menjawakan budaya Wayang, sejak awal zaman Kerajaan Majapahit diperkenalkan cerita Wayang lain yang tidak berinduk pada Kitab Ramayana dan Mahabarata. Sejak saat itulah cerita cerita Panji ; yakni cerita tentang leluhur raja-raja Majapahit, mulai diperkenalkan sebagai salah satu bentuk Wayang yang lain. Cerita Panji ini kemudian lebih banyak digunakan untuk pertunjukan Wayang Beber. Tradisi menjawakan cerita Wayang juga diteruskan oleh beberapa ulama Islam, di antaranya oleh para Wali Sanga. Mereka mulai meWayangkan kisah para raja Majapahit, di antaranya cerita Damarwulan .Masuknya agama Islam ke Indonesia sejak abad ke-15 juga memberi pengaruh besar pada budaya Wayang , terutama pada konsep religi dari falsafah Wayang itu. Pada awal abad ke-15, yakni zaman Kerajaan Demak, mulai digunakan lampu minyak berbentuk khusus yang disebut blencong pada pergelaran Wayang Kulit .

Sejak zaman Kartasura, peng-gubahan cerita Wayang yang berinduk pada Ramayana dan Mahabarata makin jauh dari aslinya. Sejak zaman itulah masyarakat penggemar Wayang mengenal silsilah tokoh Wayang, termasuk tokoh dewanya, yang berawal dari Nabi Adam . Sisilah itu terus berlanjut hingga sampai pada raja-raja di Pulau Jawa. Dan selanjutnya, mulai dikenal pula adanya cerita Wayang pakem. Yang sesuai standar cerita, dan cerita Wayang carangan yang diluar garis standar. Selain itu masih ada lagi yang disebut lakon sempalan, yang sudah terlalu jauh keluar dari cerita pakem.Memang, karena begitu kuatnya seni Wayang berakar dalam budaya bangsa Indonesia, sehingga terjadilah beberapa kerancuan antara cerita Wayang, legenda, dan sejarah. Jika orang India beranggapan bahwa kisah Mahabarata serta Ramayana benar-benar terjadi di negerinya, orang Jawa pun menganggap kisah pewayangan benar-benar pernah terjadi di pulau Jawa.

Dan di wilayah Kulonprogo sendiri Wayang masih sangatlah diminati oleh semua kalangan. Bukan hanya oleh orang tua saja, tapi juga anak remaja bahkan anak kecil juga telah biasa melihat pertunjukan Wayang . Disamping itu Wayang juga biasa di gunakan dalam acaraacara tertentu di daerah kulonprogo ini, baik di wilayah kota Wates ataupun di daerah pelosok di Kulonprogo.

\section{Wanda dalam Wayang Kulit}

Seseorang perencana/disainer Wayang, seperti layaknya seorang perencana/disainer produk, ia juga harus menetapkan suatu konsep lebih dahulu, yang akan dipakai sebagai acuan untuk melaksanakan pekerjaan perencanaan-nya. Sebagai contoh misalnya dipilih 'Wanda kinanthi' bagi tokoh Wayang Harjuna yang hendak dirancang, pada penerapannya harus terlebih dahulu dirinci seluruh unsur yang akan diterapkan pada Wayang Harjuna itu. Misalnya: bagaimana bentuk rupa muka, bagaimana bentuk rupa tubuh, bentuk rupa ragam hias, bentuk rupa muka, bagaimana bentuk rupa pola ragam hias kain batiknya, warna muka, warna badan, kelengkapan pakaian, bagaimana 'gelung', bagaimana hiasan, bentuk rupa pakaian, garis, tekstur. Artinya, secara keseluruhan (seluruh unsur), Wayang tersebut bercitra kinanthi seperti yang dimaksud. Dalam kasus ini, citra kinanthi bukan hanya ditunjukkan oleh bagian tertentu dari Wayang tersebut. Jadi, 'Wanda' atau citra pada Wayang, seharusnya diterapkan dan ditunjukkan pada seluruh bagian dari Wayang tersebut. 
Meskipun demikian, kenyataannya penerapan 'Wanda' atau 'citra' (image) pada Wayang, sebagian besar hanya berkenaan dengan beberapa hal saja, yaitu: a) Sudut muka/wajah Wayang (lebih menunduk atau lebih menengadah), b) Bentuk rupa wajah Wayang, c) Bentuk badan Wayang, d) Sudut badan Wayang (lebih tegak atau lebih condong ke arah depan), e) Warna wajah (hitam, putih, 'prada', biru, merah, atau warna lainnya). Sedangkan berbagai hal lainnya, umumnya dianggap 'bisa disamakan'. Maksudnya tidak perlu ada yang diubah, meskipun 'Wanda'-nya lain. Ini merupakan pendekatan yang paling banyak diterapkan pada Wayang. Sebagai contoh, penerapan 'Wanda gilut' pada tokoh Wayang Bagong, yang menampilkan karakter tokoh Bagong yang memberikan kesan nakal, lucu, suka membandel, suka menang sendiri, dan suka berbeda pendapat; dengan Bagong yang ber-Wanda lain, umumnya hanya terletak pada bentuk rupa wajah semata (termasuk bentuk rupa mata, alis, dan mulut). Sedangkan bagian badan lainnya, biasanya sama sekali tidak ada perbedaan dengan Bagong yang menerapkan Wanda lain.

\section{METODE PENELITIAN}

Penelitian ini menggunakan Visual Research Methodology yang merupakan penelitian dengan pendekatan practice-based, yaitu melakukan evaluasi terus menerus dengan melakukan praktik penerapan ciri-ciri yang terdapat pada Wanda yang dipilih sebagai studi kasus dalam bentuk sketsa alternatif yang mengacu pada perkembangan pemahaman yang dimiliki anak usia Sekolah Dasar berdasarkan data secondary .

Metode penelitian ini memiliki karakteristik sebagai berikut:

1. Mengumpulkan, mendokumentasikan informasi dan menghasilkan data / bukti.

2. Merefleksikan dan mengevaluasi informasi, memilih informasi yang paling relevan.

3. Menganalisis, menafsirkan dan menciptakan informasi.

4. Mensintetis dan mengkomunikasikan temuan penelitian, perencanaan penelitian baru.

5. Membuat karya seni/desain /karya kreatif melalui kerangka kerja proyek tertentu atau sebagai tubuh bekerja mengeksplorasi pertanyaan penelitian, yang mungkin mencakup, atau ditambah dengan, salah satu dari berikut:
a. Pengamatan dan terkait notasi / penggunaan simbol
b. Visualisasi
c. Menggambar (dalam segala bentuk), diagram
d. Konsep Pemetaan, pemetaan pikiran
e. Brainstroming / berpikir lateral
f. Sketchbook / notebook
g. Fotografi, video, audio
h. Eksperimen dengan bahan dan proses
i. Pemodelan / Simulasi
j. Multimedia / hypermedia aplikasi
k. Digital database, visual dan tekstual Glosari dan arsip
1. Refleksi-in-action / arus kesadaran narasi / pribadi
m. Visual Diary / reflektif Journal / diary penelitian
n. Kolaborasi / partisipasi / umpan balik, misalnya: lokakarya
o. Kurasi
p. Penulisan kritik, publikasi
q. Pameran / rekan umpan balik / review 
Penelitian ini relevan dengan pendekatan ilmu sosial yang telah di adaptasi dan mengalami re-kontekstualisasi sesuai disiplin terkait, seperti:

1. Wawancara / kuesioner, survei (mencari pendapat orang lain)

2. studi kasus - studi mendalam dari contoh yang relevan

3. peserta-observasi - peneliti sebagai peserta / kolaborator dalam penelitian

4. Metode membangun personal - membuat rasa diri kita di dunia kita

5. evaluatif Teknik - misalnya diferensial semantik

6. Perangkat lunak yang mendukung sistem metode.

\section{HASIL DAN PEMBAHASAN}

Penelitian ini bermaksud mengkaji desain karakter sebagai wajah dari industri komik dan animasi Indonesia. Desain karakter dalam komik dan animasi Indonesia tidak dikaji hanya sebagai artefak visual, tetapi diperkaya melalui kajian psikologis, semiotik dan yang relevan dalam menemukan karakteristik desain yang berhasil. Sehingga penelitian ini dapat dijadikan rujukan dalam penelitian mengenai desain karakter selanjunya.Informasi dan data dalam penelitian ini diperoleh melalui pengumpulan artefak desain karakter pada komik dan animasi Indonesia dalam serangkaian kurun, genre, dan ideologi, kemudian di kategorisasi dan saling diperbandingkan sehingga mendapatkan kesimpulan mengenai desain karakter pada komik dan animasi yang "Indonesia".Hasil penelitian ini bukan berupa karya visual, tetapi lebih kepada kategorisasi dan kode-kode yang disusun sedemikian rupa dapat digunakan untuk keperluan penelitian selanjutnya mengenai desain karakter, komik, animasi, budaya visual, dan lain sebagainya.

\section{Analisis Umum}

Dalam konteks kebudayaan, Indonesia merupakan entitas yang hampir mustahil didefinisikan secara tunggal. Kekayaan budaya bangsa Indonesia terlalu kompleks dan beragam. Indonesia bukan (katakanlah) Jepang yang relatif homogen dibandingkan bentang kekayaan budaya yang dimiliki Indonesia. Tiap sub kultur dalam budaya Indonesia memiliki ciri khasnya sendiri yang tidak selalu serupa dan sejalan, bahkan seringkali tumpang tindih dan saling bertentangan. Contoh paling sederhana, penggunaan warna dalam satu sub-kultur di Indonesia bisa ditafsirkan sangat berbeda menurut perspektif sub-kultur yang lain.Begitu juga ragam ekspresi seni dan kehidupan sosial bisa sangat berbeda di masing masing konteks kebudayaan di Indonesia.

Berbicara mengenai desain karakter, kita berbicara mengenai representasi budaya yang melahirkannya. Desain karakter tidak hanya muncul pada karya visual sepertilukis, tetapi18juga muncul pada ragam seni gerak dan pertunjukan. Ragam ekspresi, gesture dan aspek-aspek psiko-kultural suatu masyarakat berpengaruh pada desain karakter yang dihasilkan.

Suatu desain karakter tidak hanya dilihat dari aspek visual belaka, tetapi juga pasa aspek lain seperti psikologis dan semiotika yang mempengaruhi tafsir audience atas makna yang disampaikan melalui desain karakter tersebut. Seperti disampaikan mice, bahwa desain karakter itu sangat dipengaruhi oleh cerita. 


\section{Kerangka Berpikir}

\section{Pembahasan dan Analisis}

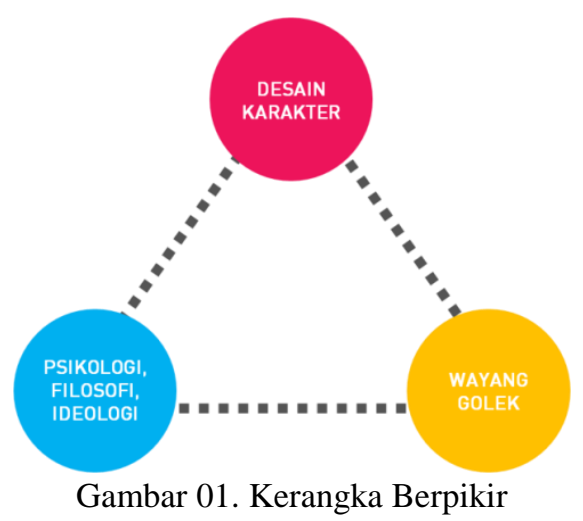

Pembahasan pada penelitian ini dilakukan dengan membandingkan desain karakter pada Wayang golek Sunda sebagaimana yang telah ditampilkan, dengan hasil eksplorasi visual menurut kategorisasi Karen Isbister dalam bukunya: Game Character Design. A Psychological Approach.

Aspek-aspek yang diperbanding-kan tersebut dikaji secara mendalam untuk mendapatkam pemahaman me-ngenai bagaimana ciri desain karakter di Indonesia, sehingga dapat dimanfaatkan dalam penelitian selanjutnya. Pada akhirnya, kajian semiotika akan memperkaya analisis penelitian ini untuk mendapatkan pemahaman lebih men-dalam mengenai aspek-aspek yang ber-kaitan dengan makna, pesan dan ideologi dalam desain karakter.

\section{Desain Karakter Menurut Permukaan Sosial (Social Surface Effect)}

Sosial surface effect atau permukaan sosial merupakan aspek dari karakter atau indivudu yang relatif tampak dan mudah diidentifikasi secara kasat mata. Secara psikologis, terdapat kecenderungan terhadap ciri-ciri karakter yang disukai. Kecenderungan ini terutama mengenai karakteristik yang kasat mata, yaitu: 1) Attractiveness; 2) Babyface Effect; 3) Stereotypes.

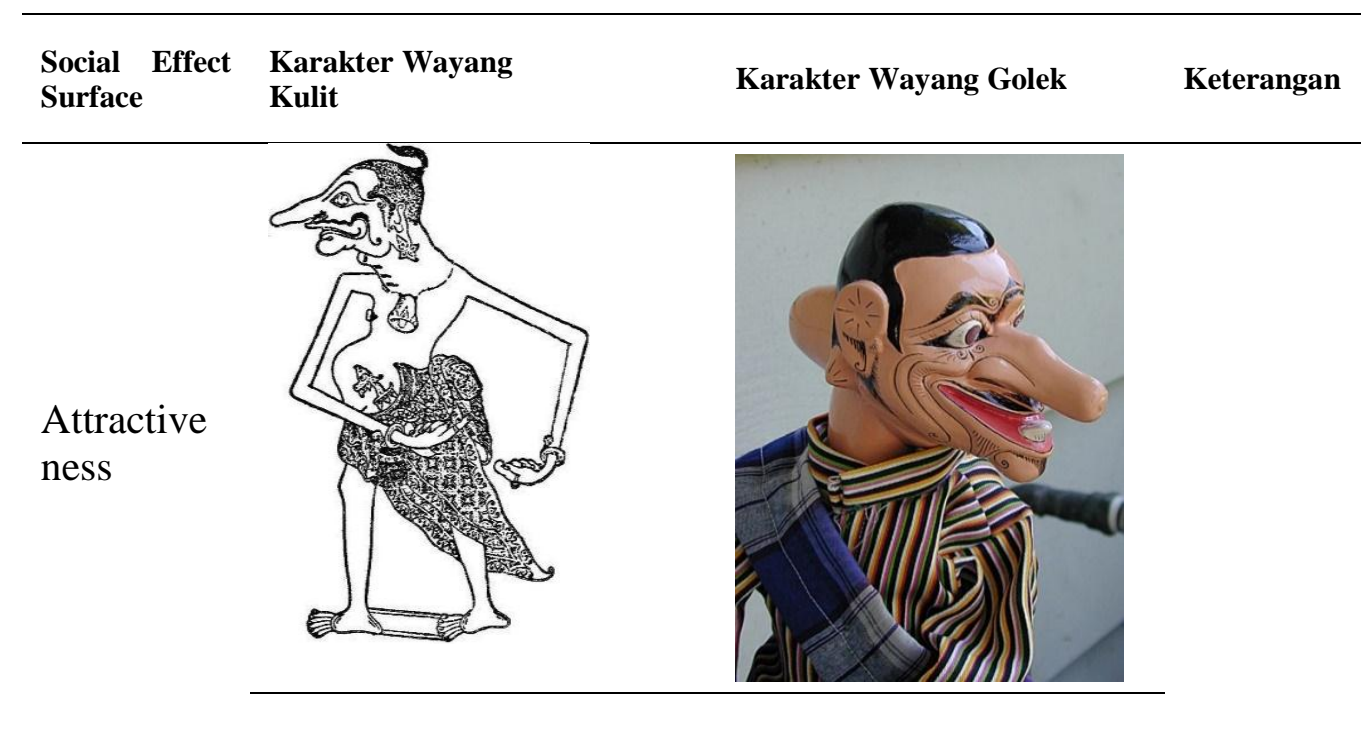




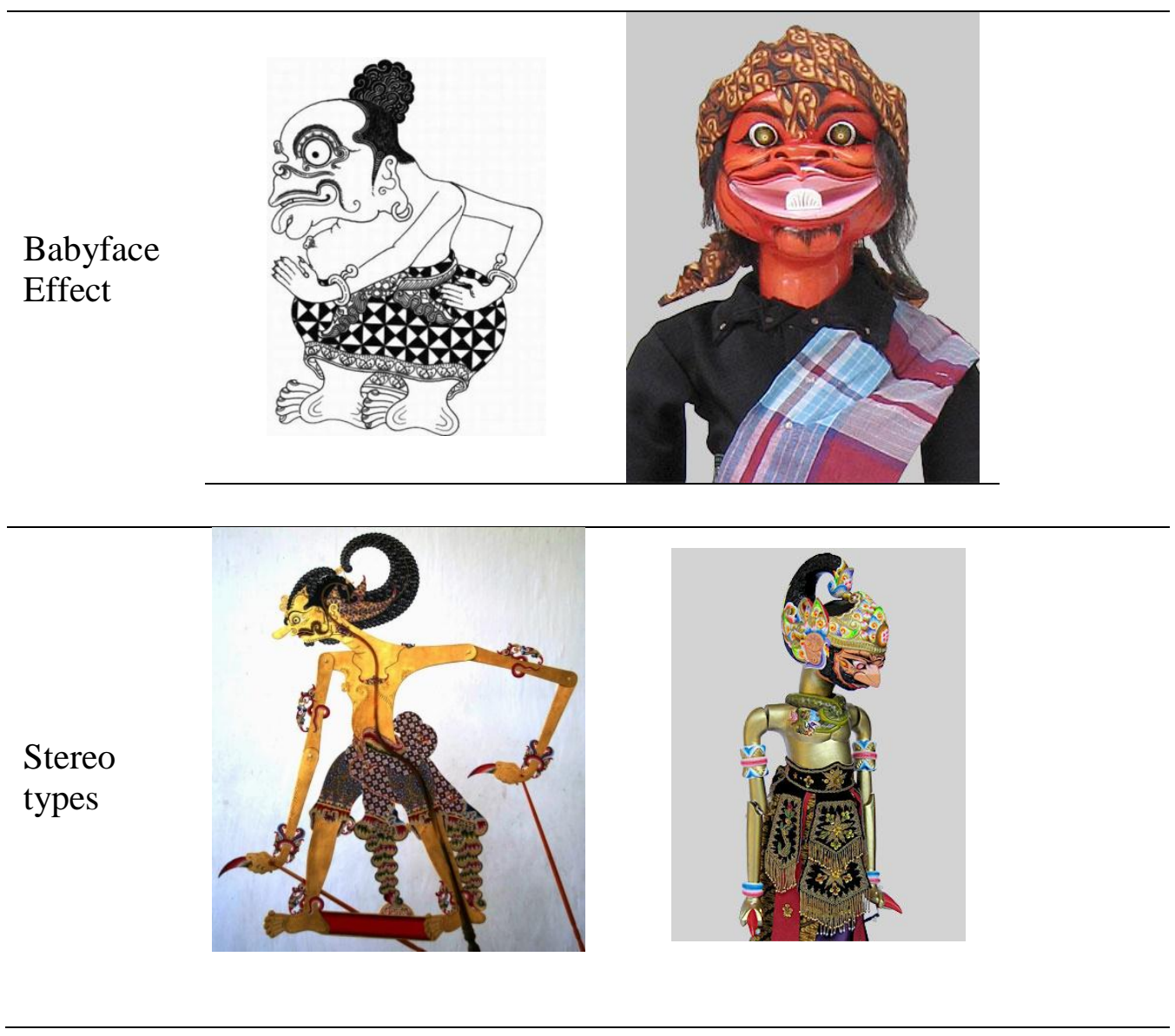

Tabel 01. Perbandingan desain karakter menurut permukaan sosial

\section{Ciri Pada Karakter}

Menurut Isbister, terdapat beberapa ciri (perbedaan) antara karakter dominan dan submisif (submissive), sebagai berikut:

\begin{tabular}{lllll}
\hline Wajah & Dominan & Submisif & & \\
& $\begin{array}{l}\text { Karakter dominan membuat lebih } \\
\text { banyak kontak mata. Mereka } \\
\text { menatap lawan bicaranya ketika } \\
\text { sedang bercakap-cakap. }\end{array}$ & $\begin{array}{l}\text { Cenderung menghindari kentak } \\
\text { Cenderung menunduk. }\end{array}$ & \\
\hline Badan & $\begin{array}{l}\text { Terbuka.Tenang. Tak banyak } \\
\text { bergerak. }\end{array}$ & $\begin{array}{l}\text { Tertutup. Gugup. Sering menyentuh } \\
\text { anggota tubuhnya sendiri. }\end{array}$ & arah \\
\hline Suara & $\begin{array}{l}\text { Keras. Dan lebih banyak } \\
\text { mendominasi pembicaraan. }\end{array}$ & $\begin{array}{l}\text { Lemah. Mengikuti } \\
\text { pembicaraan saja. }\end{array}$ & Mengiam. \\
\hline
\end{tabular}

Tabel 02. Perbandingan karakter dominan dan submisif

Dari tabel perbandingan karakter dominan dan submisif diatas, kita dapat menangkap bahwa kategorisasi tersebut relevan ketika diperbincangkan dalam konteks budaya barat, tetapi belum tentu sesuai ketika diadopsi oleh budaya lain. Sebagai contoh, menatap lawan bicara bisa diartikan sama sekali berbeda oleh orang Asia karena dianggap tidak sopan dan menantang. Sementara dalam tabel diatas yang merupakan representasi budaya Barat, hal tersebut (menatap lawan bicara) harus dilakukan sebagai wujud sopan santun. Sangat bertolak belakang. 
Perbandingan Ekspresi Emosi Dasar Karakter

Terdapat empat ekspresi emosional dasar manusia yang dapat digunakan untuk mengkaji desain karakter, meliputi: 1) Anger; 2) Fear; 3) Happiness; dan 4) Sadness.

\begin{tabular}{|c|c|c|c|}
\hline $\begin{array}{l}\text { Ekspresi } \\
\text { Emosi Dasar }\end{array}$ & $\begin{array}{l}\text { Karakter Wayang } \\
\text { Kulit }\end{array}$ & $\begin{array}{l}\text { Karakter Wayang } \\
\text { Golek }\end{array}$ & Keterangan \\
\hline $\begin{array}{l}\text { Anger } \\
\text { (Kemaraan) }\end{array}$ & $\begin{array}{l}\text { Cepengan } \\
\text { Tancepan }\end{array}$ & $\begin{array}{l}\text { Pocapan } \\
\text { Antawacana } \\
\text { Sabetan }\end{array}$ & $\begin{array}{l}\text { Cepengan menyesuaikan suasana adegan yang sedang } \\
\text { berlangsung } \\
\text { Tancepan } \\
\text { berfungsi untuk menggambarkan keadaan batin seorang } \\
\text { tokoh Wayang }\end{array}$ \\
\hline $\begin{array}{l}\text { Fear } \\
\text { (Ketakutan) }\end{array}$ & $\begin{array}{l}\text { Tancepan } \\
\text { Entas-entasan }\end{array}$ & $\begin{array}{l}\text { Pocapan } \\
\text { Sabetan }\end{array}$ & $\begin{array}{l}\text { Pocapan } \\
\text { adalah nyandra yang tidak diiringi gamelan untuk } \\
\text { menceritakan peristiwa dalam } \underline{\text { adegan }}\end{array}$ \\
\hline $\begin{array}{l}\text { Happiness } \\
\text { (Kebahagiaan) }\end{array}$ & Tancepan & $\begin{array}{l}\text { Pocapan } \\
\text { Sabetan }\end{array}$ & $\begin{array}{l}\text { Antawacana } \\
\text { Dialog antara tokoh Wayang dengan nayaga, wirasuara, atau } \\
\text { jurukawih dinamakan dialog samping } \\
\text { Sabetan } \\
\text { Sabetan adalah gerak Wayang yang meliputi tarian, lakuan, } \\
\text { dan lagaan. Tari Wayang adalah gerak Wayang yang } \\
\text { diiringan nyanyian dan gamelan. Lakuan adalah gerak } \\
\text { Wayang yang hanya diiringan kecrek atau kendang. } \\
\text { Sedangkan lagaan adalah gerak Wayang dalam peperangan } \\
\text { baik dengan iringan gamelan maupun hanya diiringi kecrek } \\
\text { dan kendang. }\end{array}$ \\
\hline $\begin{array}{l}\text { Sadness } \\
\text { (Kesedihan) }\end{array}$ & Tancepan & $\begin{array}{l}\text { Pocapan } \\
\text { Sabetan }\end{array}$ & $\begin{array}{l}\text { Entas-entasan } \\
\text { Tekhnik entas-entasan merupakan tekhnik bagaimana } \\
\text { mengeluarkan seorang tokoh Wayang dari panggung Entas- } \\
\text { entasan disesuaikan dengan situasi adegan yang sedang } \\
\text { berlangsung. Misalnya, tergesa-gesa, normal, sedih atau } \\
\text { situasi yang lain.Selain itu juga terdapat tekhnik untuk } \\
\text { mengeluarkan tokoh Wayang ketika dia mati. }\end{array}$ \\
\hline
\end{tabular}

Tabel 03. Perbandingan desain karakter menurut ekspresi emosi dasar karakter

\section{Perbandingan Peran Sosial Karakter}

Masing-masing karakter diciptakan dan memiliki peran sosial yang bermacam-macam sebagaimana yang diinginkan. Terdapat beberapa peran sosial dalam buku Karen Isbister yang lebih dimaksudkan untuk desain karakter pada game. Daftar dalam tabel berikut merupakan kategori peran sosial yang relevan dan sesuai dengan kebutuhan desain karakter

Berikut adalah kategorisasi desain karakter menurut peran sosial (social role) karakter:

\begin{tabular}{lcc}
\hline $\begin{array}{l}\text { Peran Sosial } \\
\text { Karakter }\end{array}$ & $\begin{array}{l}\text { Karakter } \\
\text { Wayang } \\
\text { Kulit }\end{array}$ & $\begin{array}{l}\text { Karakter } \\
\text { Wayang } \\
\text { golek }\end{array}$ \\
\hline Karakter Utama & $\mathrm{V}$ & $\mathrm{V}$ \\
\hline Minion & $\mathrm{V}$ & $\mathrm{V}$ \\
\hline Rescuee & $\mathrm{V}$ & $\mathrm{V}$ \\
\hline Sidekick & $\mathrm{V}$ & $\mathrm{V}$ \\
\hline Ally & $\mathrm{V}$ & $\mathrm{V}$ \\
\hline Guide/ Mentor & $\mathrm{V}$ & $\mathrm{V}$ \\
\hline
\end{tabular}




\begin{tabular}{lcc}
\hline $\begin{array}{l}\text { Obstacle/ } \\
\text { Competitor }\end{array}$ & $\mathrm{V}$ & $\mathrm{V}$ \\
\hline Enemy & $\mathrm{V}$ & $\mathrm{V}$
\end{tabular}

Tabel 04. Perbandingan desain karakter menurut peran sosial karakter

Berikut adalah penjelasan dari masing-masing peran sosial karakter:

1. Karakter Utama: Karakter yang menjadi pusat perhatian dalam suatu komik atau animasi. Biasanya me-miliki keunggulan tertentu entah ke-kuatan fisik, intelektualitas, agresivitas atau yang lain.

2. Minions: Adalah karakter yang secara sosial kurang dominan dan ber-peran sebagai "pembantu" karakter utama. Minion selalu tunduk pada karakter utama.

3. Rescuee: Adalah karakter yang kurang dominan yang hampir selalu menjadi objek penyelamatan dari karakter utama..

4. Sidekick: Adalah karakter pen-dukung yang relatif seimbang peran sosialnya dengan karakter utama. Sidekick bisa bersifat sebagai sekutu, tetapi bisa juga terkadang digambarkan sebagai sosok yang mengganggu atau sekaligus keduanya.

5. Ally/ Allies: Adalah karakter yang memiliki derajat sosial seimbang dan cenderung menjadi sekutu karakter utama.

6. Guide/ Mentor: Adalah karakter yang memiliki derajat sosial lebih tinggi daripada karakter utama dan berperan sebagai guru

7. Obstacle/ Competitor: Adalah karakter yang cenderung memberikan gangguan walaupun tidak selalu menjadi musuh.

8. Enemy/ Enemies: Adalah musuh utama bagi karakter utama.

Kategorisasi karakter menurut peran sosial diatas tidak harus berlaku secara kaku tetapi bisa saling tumpang tindih antar karakter. Satu karakter bisa jadi memiliki lebih dari satu peran sosial.

Dari analisis diatas, kita dapat menyimpulkan juga bahwa peran sosial berlaku baik dalam desain karakter Amerika maupun Jepang, sedangkan dalam desain karakter kontemporer di Indonesia masih sulit mengisi kategorisasi tersebut karena belum banyak karakter komik dan animasi yang "established" dan dapat secara tepat dimasukkan dalam kategorisasi tersebut diatas.

\section{Perbandingan Asesoris dan Atribut}

Membicarakan hal ini sudah pasti tidak akan terlepas dari rancangan bentuk Wayang itu sendiri, dalam Wayang kulit dikenali cara perancangan bentuk yang memiliki estetika bentuk tersendiri sehingga proposi Wayang tidak mengacu pada bentuk manusia. Wayang golek memiliki proporsi yang lebih mendekati proporsi tubuh manusia.

Perbandingan visual pada asesoris dan atribut dari akan memberi gambaran yang cukup dalam hal mengenali bagaimana seniman Wayang men-terjemahkan deskripsi yang berbentuk verbal menjadi hadir dalam bentuk visual. Boleh jadi sedikit banyak akan ada perbedaan, penambahan atau pengurang-an berdasarkan interpretasi individu senimannya. 


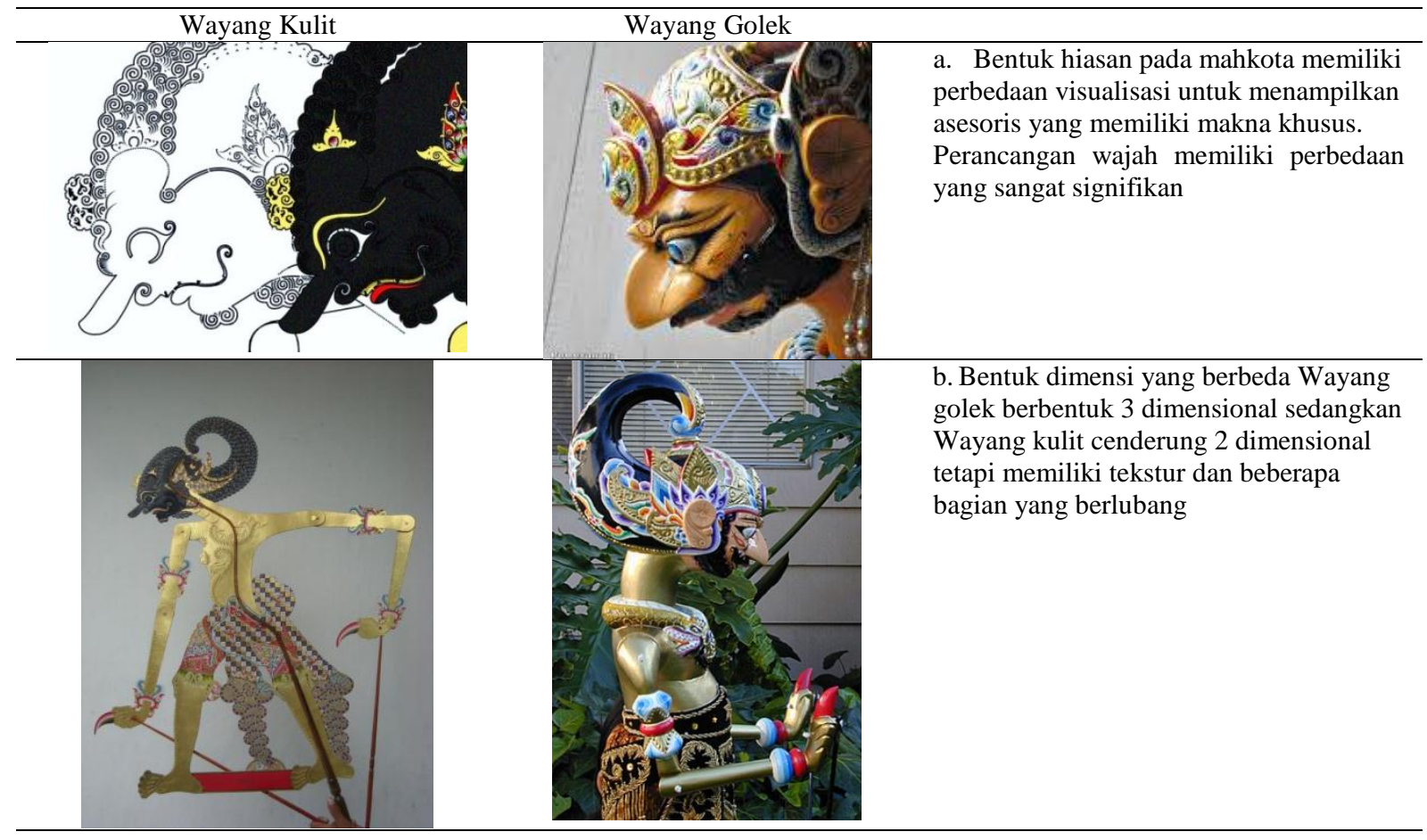

\section{Wanda Wayang Bima} berikut:

Werkudara atau Bima mempunyai beberapa Wanda yang namanya adalah sebagai

\footnotetext{
Lindhu PaNon yang mempunyai arti Lindu artinya gempa sedangkan paNon mempunya arti mata ketika werkudara waktu pagelaran Wayang menampakkan Wanda yang seperti ini werkudara sedang marah pikiranya kacau balau sampai gelap mata

cirinya : leher manglung, badan gemuk pajeg, bahu depan lebih rendah,

pencipta : mangkurat agung dari mataram 1578, jawa
}

Lindhu Bambang yang artinya muda, Wanda ini menggmbarkan bima mempunya wajah yang tampan dan agak muda

cirinya : muka menunduk, bahu belakang lebih tinggi badan agak kurus adeg angrong, gelung kecil, pencepta : PB IV surakarta $1753 \mathrm{M}$ tetapi memiliki tekstur dan beberapa bagian yang berlubang 


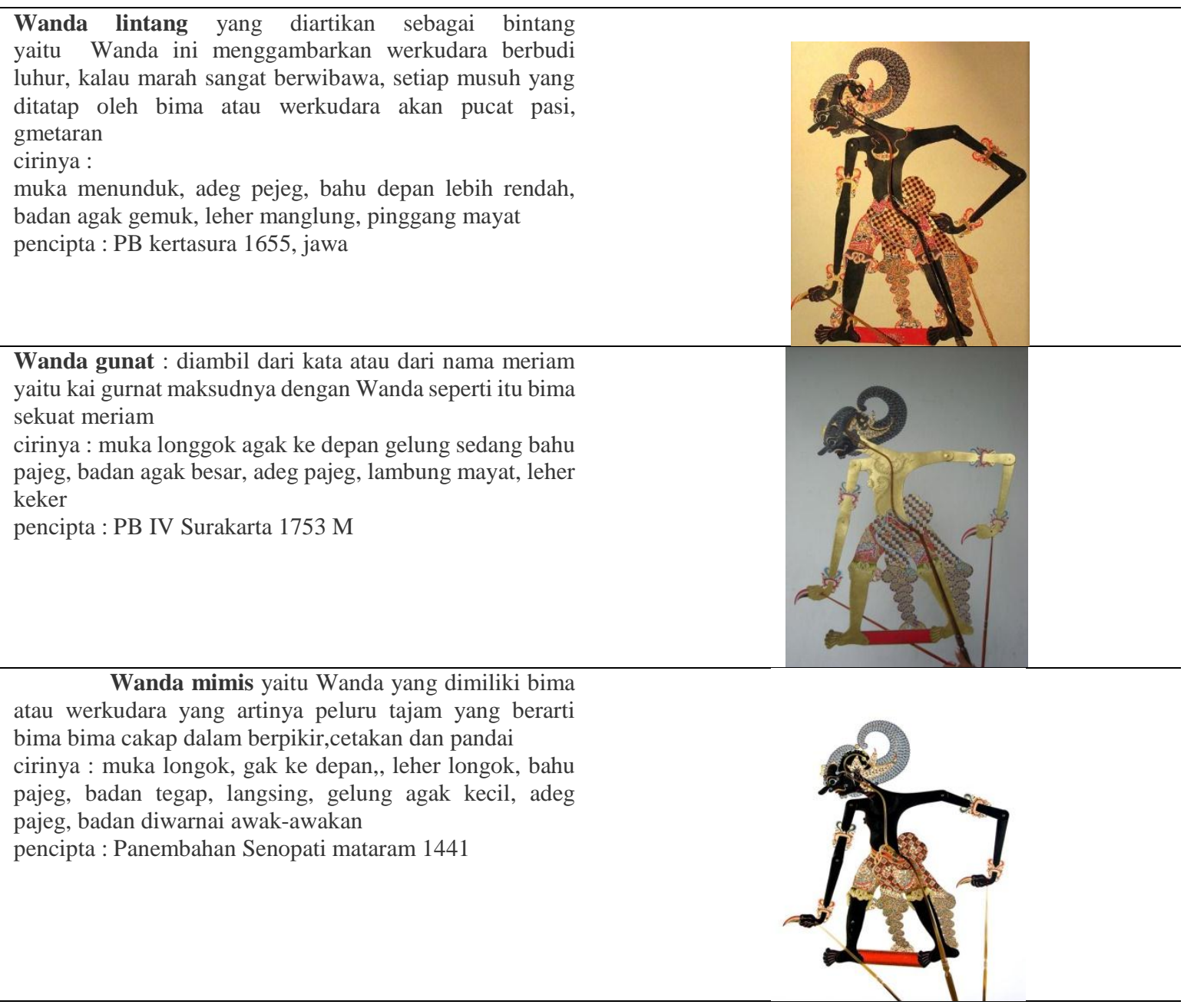

\section{Kategorisasi Bima}

\begin{tabular}{|c|c|c|c|}
\hline $\begin{array}{l}\text { Surface } \\
\text { Effect }\end{array}$ & Attractiveness & $\begin{array}{l}\text { Berhubungan } \\
\text { Wayang menja } \\
\text { menghadirkan }\end{array}$ & $\begin{array}{l}\text { gan peran sosial karena secara visual akan dapat dibedakan saat } \\
\text { bagian dalam sebuah alur cerita yang memiliki pembabakan yang } \\
\text { disi yang berbeda. }\end{array}$ \\
\hline \multirow[t]{3}{*}{$\begin{array}{c}\text { Ciri } \\
\text { Karakter }\end{array}$} & Dominan & \begin{tabular}{l|l} 
Wajah \\
\end{tabular} & $\begin{array}{l}\text { Karakter dominan membuat lebih banyak kontak mata. } \\
\text { Mereka menatap lawan bicaranya ketika sedang bercakap- } \\
\text { cakap. }\end{array}$ \\
\hline & & Badan & Terbuka.Tenang. Tak banyak bergerak. \\
\hline & & Suara & Keras dan lebih banyak mendominasi pembicaraan. \\
\hline $\begin{array}{l}\text { Ekspresi } \\
\text { Emosi } \\
\text { Dasar }\end{array}$ & $\begin{array}{c}\text { Anger, fear, happy } \\
\text { and sad }\end{array}$ & \multicolumn{2}{|c|}{$\begin{array}{l}\text { Dalam perancangan karakter, penggambaran ekspresi emosi merupakan set yang } \\
\text { disediakan guna menunjang kehadiran karakter tersebut ketika harus berperan sebagai } \\
\text { bagian dari perhatian audiens. }\end{array}$} \\
\hline $\begin{array}{l}\text { Peran } \\
\text { Sosial }\end{array}$ & Karakter Utama & \multicolumn{2}{|c|}{$\begin{array}{l}\text { Karakter yang menjadi pusat perhatian dalam suatu komik atau animasi. Biasanya } \\
\text { memiliki keunggulan tertentu entah kekuatan fisik, intelektualitas, agresivitas atau yang } \\
\text { lain. }\end{array}$} \\
\hline
\end{tabular}

\section{SIMPULAN}

Wayang (Kulit dan Golek) merupakan kekayaan budaya nasional yang dapat digali sebagai sumber pengembangan desain karakter nasional yang saat ini belum menemukan bentuknya. Desain karakter merupakan bagian penting dalam industri kreatif sperti komik, animasi, film, dan game. Karakter bukan sekedar "aktor" tetapi sekaligus juga merupakan representasi ideologis dari pembuat komik dan animasi yang dirancang sedemikian rupa agar 
mampu berkomunikasi secara lebih intim dan intensif melalui bahasa visual tertentu. Karakter, disadari atau tidak, memiliki peran begitu mendasar sebagai duta besar atas pesan dan gagasan yang sedang dibangun oleh pembuat komik dan animasi. Keberhasilan suatu komik dan animasi seringkali ditentukan oleh karakternya.

Sayangnya, perhatian kepada desain karakter dalam komik dan animasi Indonesia masih terbatas pada eksplorasi visual yang seringkali dangkal dan mudah dilupakan karena tidak "hidup". Untuk itu kajian mendalam mengenai desain karakter dengan pengkayaan pada aspek non visual seperti psikologis dan semiotika sangat penting untuk menemukan formula dalam rangka "menghidupkan" karakter tersebut.

Desain karakter di Indonesia belum bisa melepaskan diri dari bayang-bayang tren dan hegemoni gaya visual asing. Desain karakter di Indonesia masih berkutat pada terjemah visual yang literal dari apa yang disebut sebagai local content. Karakter-karakter Indonesia muncul dalam aneka bungkus visual mengikuti tren industri yang men-dominasi dan sedikit sekali karakter yang lahir bersama ciri Indonesia yang khas dalam arti sebenarnya. Untuk itu kemudian dilakukan komparasi terhadap desain karakter komik dan animasi asing dominan dengan tujuan menemukan ciri khas yang bisa dikembangkan sebagai kekuatan potensial di masa mendatang.

Penelitian ini setidaknya memberi-kan gambaran awal mengenai aspek-aspek visual dan non visual yang harus diperhatikan dalam upaya menemukan formulasi desain karakter (yang) Indonesia melalui sumber kekayaan budaya nusantara, yaitu Wayang ( Kulit dan Golek). Desain karakter dalam Wayang dianalisis dan di eksplorasi menurut kategorisasi yang disampaikan terutama oleh Karen Isbister dalam bukunya: Game Character Design. A Psychological Approach sehingga mem-berikan pemetaan dan gambaran yang komprehensif terutama mengenai aspek-aspek dalam desain karakter tersebut dalam konteks kekinian untuk mendukung industri kreatif seperti komik, animasi, game, mobile content, dan sebagainya. Meskipun titik berat kategorisasi ini adalah teori psikologi, tetapi hasil penelitian ini adalah eksplorasi simbol-simbol visual yang dapat dimanfaatkan sebagai landasan dalam eksplorasi desain karakter selanjut-nya berbasis kekayaan budaya Indonesia lainnya.

Akhirnya, penelitian ini masih jauh dari sempurna. Tetapi sebagai suatu langkah awal dalam tradisi penelitian visual, maka penelitian ini diharapkan memberikan kontribusi dalam dunia desain, komunikasi visual, dan animasi khususnya di Indonesia.

Dalam perkembangannya, industri kreatif di Indonesia termasuk komik dan animasi Indonesia kurang memberikan perhatian memadai pada desain karakter. Karakter hanya identik dengan artefak visual tanpa diperkaya kajian mendalam mengenai hal-hal yang berkaitan dengan pengembangan karakter diluar aspek visual. Padahal proses menghidupkan suatu karakter harus mencakup berbagai aspek secara menyeluruh seperti visual, psikologis, simbol, ideologi, dan sebagainya.

Minimnya perhatian terhadap desain karakter pada komik dan animasi lokal diperparah dengan hegemoni produk-produk impor yang memberikan pengaruh luar biasa tidak saja kepada para pembaca dan pemirsa, tetapi juga kepada para kreator komik dan animasi di Indonesia. Terutama komik, saat ini banyak sekali kita temukan tema-tema lokal yang dikemas dalam balutan gaya desain karakter hasil impor. Tidak salah memang, tetapi fenomena tersebut sangat layak untuk dikaji sehingga di masa mendatang kita tidak sekedar mengadaptasi atau bahkan meniru gaya desain karakter impor, tetapi bisa menemukan suatu gaya tersendiri yang bisa dibanggakan. Penelitian ini diharapkan bisa memberikan kontribusi dalam pengembangan desain karakter di Indonesia. 


\section{DAFTAR PUSTAKA}

Haryanto, S. (1991). Seni Kriya Wayang Kulit: Seni Rupa, Sunggingan dan Tatahan. Jakarta: Grafiti.

Isbister, K. (2006). Better Game Characters by Design: A Psychological Approach, San Fransico, Morgan Kauffmann Publisher.

Kusano, Y. (2003). Super Character Design \& Poses, Tokyo, MPC Publishing.

Mattesi, M. D., (2008). Force Character Design from Life Drawing, Burlington, Focal Press.

Tillman, B. (2011). Creative Character Design, Kidlington, Focal Press.

Weintraub, A. N., (2004). Power Plays: Wayang Golek Puppet Theater of West Java, Ohio University Press. 